\title{
Feeding behaviour and pugmark analysis of elephants in Sarguja, Chhattisgarh
}

\author{
A. K. Thakur, D. K. Yadav and M. K. Jhariya* \\ Department of Farm Forestry, Sarguja University, Ambikapur-497001 (C.G.), INDIA \\ *Corresponding author. E-mail: manu9589@gmail.com
}

Received: February 22, 2016; Revised received: August 4, 2016; Accepted: November 7, 2016

\begin{abstract}
The pugmark analysis of the elephants offers basic information to track the wild elephant migratory route, identification and census. For its study, four blocks viz, Sitapur, Lundra, Batouli (Sarguja district) and Farsabahar (Jashpur district) of northern Chhattisgarh were selected because these blocks are commonly visited by elephants and a major path route of movement of heard in inter/intra state. The most commonly consumed species belongs to family poaceae $(22.58 \%)$ followed by fabaceae $(19.35 \%)$ but their diet was mainly dependent on availability of seasonal food round the year and on their migration. Elephants extensively fed on Artocarpus heterophyllus, Syzygium cumini, Acacia nilotica, A. catechu, Dalbergia sissoo, Zizyphus mauritiana, Aegle marmelos and Ficus species, besides these elephants also utilized various grasses and shrubs as their food, which mainly included Dendrocalamus strictus, Cynodon dactylon etc. Elephants sometimes spent long time to feed on some particular plant species like D. strictus and Ficus species. Crop raiding, which was sporadic during the rainy season, gradually increased with more area being cultivated with the onset of monsoon. Analysis of pugmark revealed that the circumference varied from $63.80 \mathrm{~cm}$ to $172.70 \mathrm{~cm}$ whereas length $\mathrm{x}$ width varied from $22 \times 20 \mathrm{~cm}$ to $60 \times 55 \mathrm{~cm}$, which reflects a substantial variation/differentiation of individual in heard in respect of their age, sex, size etcTherefore, management implications are needed to conserve the corridors for their long term survival and reduction of HEC. The study will be helpful to provide key information and facilitate better understating of the scenario to the forest department, policy maker and conservationist to plan, manage and improve the habitat towards the restoration and afforestation of suitable palatable species preferred by elephants of northern corridors of Chhattisgarh.
\end{abstract}

Keywords: Asian elephant, Corridor, Feeding behavior, Habitat, Pugmark analysis

\section{INTRODUCTION}

The northern region of Chhattisgarh substantially has large elephant population. However, there are only a few protected areas in this region of which Guru Ghasidas National Park, Tamorpingla Wildlife Sanctuary, Semrasot Wildlife sanctuary and Badalkhol Wildlife sanctuary are the largest intact natural habitat available for elephants (Thakur et al., 2015). The remaining natural habitats include man modified habitats such as forest plantations and abandoned agricultural lands which are in different stages of natural succession. Elephants are generalist feeders, consuming a large number of plant species (Borah and Bhuyan, 2016). India has largest population of wild Asian elephants (about 27000-29000), (MoEF, 2010). Numerous studies on feeding habits of African and Asian elephants have shown that proportions of various plant categories in the diet vary widely from one region to another and cause of HEC (Sukumar, 1985; Areendran et al., 2011; Gubbi, 2012; Prabu and Kumar, 2016; Senthilkumar et al., 2016). Grasses, shrubs, tree leaves, aquatic plants and occasionally fruits make up the components of their diet. Elephants are classified as mega herbivores and consume up to $150 \mathrm{~kg}$ of plant matter per day (McKay, 1973; Vancuylenberg, 1977).
Therefore, availability of food is a major determinant of carrying capacity of elephants in a given area. Studies on feeding behavior of Sri Lankan elephants have shown that they feed on a wide variety of food plants (Mueller-Dombois, 1972; McKay, 1973; Ishwaran, 1983; Santiapillai and Read, 2010; Dharmaratne and Magedaragamage, 2014).

Northern Chhattisgarh in central India has been home of Asian elephants since historical times, however, in the early part of the $20^{\text {th }}$ century they became locally extinct. Currently over 300 elephants are found in the state. Since then, HEC has been increasing due to straying of migratory elephants in the state (Singh, 2002). Major reason for prolonged stay of elephants in the Chhattisgarh state may due to better forest cover (44\%), heavy mining, habitat degradation and deforestation in the states of Jharkhand and Orissa (Singh, 2002; EMS, 2008; Thakur et al., 2015). Sarguja division is primarily inhabited by tribal communities which are dependent largely on agriculture and forest produces. Any incidence of HEC directly interfere the socioeconomic status and livelihood of the people, posing challenges for conservation. Managing HEC is one of the greatest challenges now for conservation (Thakur et al., 2015). As majority of the elephants in the study region occupy habitats outside protected are- 
as, it is important to understand the availability of food for these elephants in order to properly manage their population. The aim of this investigation was to identify the food plants of elephants that range in the region and to assess their availability both in and outside protected areas.

\section{MATERIALS AND METHODS}

The study on feeding behaviour and pugmark analysis of elephants in and around Sarguja region of Chhattisgarh was carried out at four blocks viz., Lundra, Batouli, Sitapur and Farsabahar. The study area lies between $23^{\circ} 37^{\prime} 25^{\prime \prime}$ ' to $24^{\circ} 6^{\prime} 17^{\prime \prime}$ ' north latitude and $81^{\circ} 31^{\prime} 40^{\prime \prime}$ to $84^{\circ} 4$ ' $40^{\prime \prime}$ ' east longitude. Sarguja forest division bounds to various protected areas (Badalkhol, Semrasot, Tamorpingla sanctuary and Guru Ghasidas national park) which support a substantial number of wild elephants. Neighboring villages of the corridors are oftenly visited by the elephants during the year and causes subsequent loss of crops, property and life. The climate of the region is characterized by hot summer and well distributed rainfall during the monsoon. The chief feature of climate is long dry period; average monthly temperature rising over $18^{\circ} \mathrm{C}$, through maximum summer temperature may even go up to $46^{\circ} \mathrm{C}$. The flora of Nazzul and other areas are changing frequently with the human activities and landuse. Physiographically, they are remarkable land-forms and average height of area varies from 600 meter and more (Sinha et al., 2014 and 2015; Yadav et al., 2015; Jhariya and Yadav, 2016).

The study area was surveyed in depth during the year 2014-2015. The entire frame of the study is categorically built on rigorous field investigation and observation in consultation with forest department and the local residents. After preliminary survey of the HEC affected areas, collection of information from the households $(10 \%$ of the total households of the villages) was done by questionnaire method, informal interviews, participatory rural appraisal, transact walk and personal observations (Chambers, 1994). In order to collect the exact information only victims of HEC were concerned from each block i.e., Lundra, Batouli, Sitapur and Farsabahar to understand the feeding behaviour and pugmark measurement of elephants. Victims were identified after preliminary survey followed by discussion with residing people. Then they were interviewed and the conversation followed with documented. Primary sources of data included extensive field investigations in HEC areas by asking some specific questions such as existing problems, elephant behaviour, their movement, crop fed or species preferred, elephant entry track, their stay in the region, exit track to measure the pugmarks thereafter, results were documented along with opinion and expression of the respondents. Besides, elephant's traditional movement tracks along with feeding grounds were searched and observed directly. Field binocular was also used for observing their feeding behaviour without disturbing the animal from an adequate and safe distance. Record was based on direct sighting of animal's feeding, indirect evidences like feeding sign; pugmarks impression time and fresh dung piles. All plants on which elephants were observed to feed in the study area were identified by discussing with the local people and literature.

The analysis of pugmark was done by measuring sufficient number of impression of pugmarks available in different sites to draw a suitable conclusion in this perspective. The impression of pugmark was measured for its dimensions viz., length and width (diameter) in each block. The total measured pugmarks were categorized into different size classes and their respective values were converted into percentage.

\section{RESULTS AND DISCUSSION}

Ecological analysis of study site: During the study it was found that the $90 \%$ respondents lived in study area over 20 years and $87.50 \%$ people were native of the area (Table 1). It is found that $89.5 \%$ of population have permanent homestead. Among the different pressing issues related to farming in the study area the major obstacle was wild life especially the elephants $(72 \%)$. The felling of standing trees in the study area was for timber/poles for construction purpose $(67.50 \%)$ followed by firewood $(30 \%)$. Most of the respondents aware $(52.50 \%)$ that the rate of deforestation or habitat destruction of elephant was increasing through felling in the study area. Majority of respondents $(57.50 \%)$ found that wildlife is declining in the area because of too much hunting (65.0\%) and 55.0\% of respondents are in favor to stop hunting completely.

Pugmark analysis of elephant: Pugmark is the footprint of animal and every individual animal species has a distinct pugmark and as such this is used for identification, census and also used for tracking animal. It is possible to make an accurate identification of species, sex, age and physical condition of an animal by those trained in the field. During the analysis of pugmark in the study site it was found that the circumference varied from $63.80 \mathrm{~cm}$ to $172.70 \mathrm{~cm}$ whereas length $\mathrm{x}$ width varied from $22 \times 20 \mathrm{~cm}$ to $60 \times 55 \mathrm{~cm}$, which reflects a substantial variation/differentiation of individual in heard in respect of their age, sex, size etc.

Feeding of plants by elephant in study area: The flora selected by elephants as a food in the Sarguja region consisted of grasses, shrubs, tree leaves, bark, aquatic plants and sometimes fruits. A total of 31 plants species were recorded, which were observed to be favorite fodder species for elephants. During the study period, it was observed that elephants fed on about 8 species of grasses and 23 species of trees (Table 3). The most commonly consumed species belongs to family poaceae $(22.58 \%)$ followed by fabace- 
A. K. Thakur et al. / J. Appl. \& Nat. Sci. 8 (4): 2060-2065 (2016)

Table 1. Percentages showing ecological analysis in the study site.

\begin{tabular}{|c|c|}
\hline Query & $(\%)$ \\
\hline \multicolumn{2}{|l|}{ How long have you lived in this area? } \\
\hline Less than 10 years & 10.00 \\
\hline $10-20$ years & 0.00 \\
\hline over 20years & 90.00 \\
\hline \multicolumn{2}{|c|}{ Give reasons why you moved into this area } \\
\hline Native of the area & 87.50 \\
\hline Farming & 12.50 \\
\hline \multicolumn{2}{|l|}{ Your homestead } \\
\hline $\begin{array}{l}\text { Permanent } \\
\end{array}$ & 89.50 \\
\hline Temporary & 10.50 \\
\hline \multicolumn{2}{|c|}{ If you are engaged in farming, what are the pressing issues? } \\
\hline lack of fertilizer & 35.00 \\
\hline lack of land & 42.50 \\
\hline lack of markets & 2.50 \\
\hline low rain fall & 32.50 \\
\hline wild life & 72.00 \\
\hline \multicolumn{2}{|l|}{ Area Problems } \\
\hline lack of health facilities & 55.00 \\
\hline lack of school & 5.00 \\
\hline no grazing area for livestock & 20.00 \\
\hline \multicolumn{2}{|c|}{ Fisheries issues - are you engaged in fishing? } \\
\hline Yes & 30.00 \\
\hline No & 70.00 \\
\hline \multicolumn{2}{|l|}{ If you are, do you do it for } \\
\hline Subsistence reasons & 25.00 \\
\hline \multicolumn{2}{|c|}{ What are the common fishing methods used? } \\
\hline Nets & 27.50 \\
\hline Fishing traps & 27.50 \\
\hline \multicolumn{2}{|c|}{ If you have been cutting trees, which of the following apply } \\
\hline Timber or poles for building & 67.50 \\
\hline Charcoal $\mathrm{r}$ (he & 20.00 \\
\hline Clear land for agriculture & 27.50 \\
\hline Fire wood & 30.00 \\
\hline Hand craft & 12.50 \\
\hline \multicolumn{2}{|l|}{ Do you think cutting of trees is- } \\
\hline Increasing & 52.50 \\
\hline Decreasing & 17.50 \\
\hline Don't know & 30.00 \\
\hline \multicolumn{2}{|l|}{ Do you hunt wild animals- } \\
\hline Yes & 15.00 \\
\hline No & 85.00 \\
\hline \multicolumn{2}{|c|}{ What are the common hunting methods in your area? } \\
\hline Snaring & 12.50 \\
\hline Pit falls & 7.50 \\
\hline \multicolumn{2}{|c|}{ If you hunt, for what reason do you do it? } \\
\hline Meat for domestic consumption & 10.00 \\
\hline \multicolumn{2}{|l|}{ Do you hunt birds? } \\
\hline Yes & 27.50 \\
\hline \multicolumn{2}{|c|}{ Which of the following birds do you hunt } \\
\hline Geese & 10.00 \\
\hline & 30.00 \\
\hline \multicolumn{2}{|c|}{ Do you think wildlife is declining in your area? } \\
\hline Yes & 57.50 \\
\hline Not sure & 20.00 \\
\hline \multicolumn{2}{|l|}{ Give reasons if there is a decline } \\
\hline Too much hunting & 65.00 \\
\hline Shortage of land & 5.00 \\
\hline No protection & 40.00 \\
\hline Don't know & 40.00 \\
\hline What do you think should be done & \\
\hline Hunting birds should be stopped & 20.00 \\
\hline Hunting animals should be stopped & 55.00 \\
\hline
\end{tabular}


ae $(19.35 \%)$. Generally elephants fed in the early hours of the morning and most markedly in the evenings, just before dark. They were observed to feed in mid-day hours in winter but in summer, they rested during midday. It was observed during the study period that sometimes elephants were continuously feeding throughout the night. In summer, they spent their nights in open forest areas and when the day advanced they move towards the denser forest. In evening when the sun begins to set they again came out of the thick forest cover into the open forest areas. In Sarguja region elephants fed on the tree species like Artocarpus heterophyllus (Kathal), Dalbergia sissoo (Shisham), Zizyphus mauritiana (Ber), Aegle marmelos (Bel), Ficus bengalensis (Bargad), Ficus glomerata (Gular), Bombax ceiba (Semal), Acacia catechu (Khair), Bauhinia variegata (Kachnar), Syzygium cumini (JamunBesides elephants also used various grasses and

Table 2. Pugmark analysis of elephant.

\begin{tabular}{lll}
\hline Class in cm & Length & Width \\
\hline $20-30$ & $25 \%$ & $35 \%$ \\
$30-40$ & $30 \%$ & $40 \%$ \\
$40-50$ & $25 \%$ & $15 \%$ \\
$50-60$ & $10 \%$ & $10 \%$ \\
$>60$ & $10 \%$ & $00 \%$ \\
\hline
\end{tabular}

shrubs as their food resources, which included Dendrocalamus strictus (Bamboo), Saccharum spontaneum (Kans) and Cynodon dactylon (Doob Grass). Sarguja region falls in tropical deciduous forest type and hence one can assume that in this region, elephants eat seasonal food resources to provide the necessary range of nutrients. There is a distinct difference in the quantity and number of fruit species eaten by elephants and this influences elephant's feeding behaviour. As fruits abundance (A. marmelos, Z. mauritiana, S. cumini and Ficus species) increases during various seasons, therefore, elephants consumed.

Usually elephants do not confine to a particular area for a longtime. They tend to migrate in a determine fixed route called the elephant corridor. They use this permanent path year after year and sometimes generation after generation (Borah and Bhuyan, 2016). Therefore, pugmark analysis is an important information to track the wildlife, their migratory route, indentification and census. Furthermore, it is possible to make an accurate identification of species, sex, age and physical condition of an animal by those trained in the field by using these footprints. The migration/ movement patterns of elephants were considered to be one of the key ecological factors which influences the distribution of herbivores. Elephants move long dis-

Table 3. Elephant food and their life form in Sarguja forest division.

\begin{tabular}{|c|c|c|c|}
\hline Local name & Botanical name & Family name & Life form \\
\hline Babul & Acacia nilotica & Fabaceae & Tree \\
\hline Banana & Musa paradisiacal & Musaceae & Tree \\
\hline Bans & Dendrocalamus strictus & Poaceae & Grass \\
\hline Bargad & Ficus bengalensis & Moraceae & Tree \\
\hline Bel & Aegle marmelos & Rutaceae & Tree \\
\hline Ber & Zizyphus mauritiana & Rhamnaceae & Tree \\
\hline Doobi & Cynodon dactylon & Poaceae & Grass \\
\hline Gular & Ficus glomerata & Moraceae & Tree \\
\hline Jamun & Syzygium cumini & Myrtaceae & Tree \\
\hline Jangal Jalebi & Pithecellobium dulce & Fabaceae & Tree \\
\hline Kachnar & Bauhinia variegate & Fabaceae & Tree \\
\hline Kadam & Anthocephalus cadamba & Combrataceae & Tree \\
\hline Kans & Saccharum spp. & Poaceae & Grass \\
\hline Kathal & Artocarpus heterophyllus & Moraceae & Tree \\
\hline Khair & Acacia catechu & Fabaceae & Tree \\
\hline Kogon ghas & Imperata cylindrical & Poaceae & Grass \\
\hline Kusum & Schleichera oleosa & Sapindaceae & Tree \\
\hline Mahua & Madhuca indica & Sapotaceae & Tree \\
\hline Maize & Zea mays & Poaceae & Grass \\
\hline Motha/kandi & Cyperus rotundus & Cyperaceae & Grass \\
\hline Neem & Azadirachta indica & Meliaceae & Tree \\
\hline Paddy & Oryza sativa & Poaceae & Grass \\
\hline Pipal & Ficus religiosa & Moraceae & Tree \\
\hline Sagwan & Tectona grandis & Lamiaceae & Tree \\
\hline Saja & Terminalia tomentosa & Combrataceae & Tree \\
\hline Sal & Shorea robusta & Dipterocarpaceae & Tree \\
\hline Semal & Bombax ceiba & Bombaceae & Tree \\
\hline Senha & Lagerstroemia parviflora & Lythraceae & Tree \\
\hline Shisham & Dalbergia sissoo & Fabaceae & Tree \\
\hline Siris & Albizzia spp. & Fabaceae & Tree \\
\hline Sugarcane & Saccharum officinarum & Poaceae & Grass \\
\hline
\end{tabular}


tances as part of their migration activities and at the same time they stay within different forest habitats and/or forest fringe areas that are enriched with ample supply of water and fodder (Hedges and Gunaryadi, 2009; Graham et al., 2010).

The food resources crucial to elephants in natural condition were studied. Food preference by elphants in present study clearly shows that they were attracted to some specific food plants possibly due to their high palatability, protein content or mineral values as suggested by Sukumar (1991). The study reveals that the food supply of E. maximus consist of grasses, shrubs, tree leaves, bark and also the fruits. The major grasses were Imperata cylindrica, Oryza sativa, Zea mays, Saccharum officinarum, D. strictus etc. and the plants or tree leaves were A. heterophyllus, F. species, Musa paradisiaca, Acacia species etc. Similar findings were also reported by Sivaganesan and Johnsingh (1995) who found that grass formed the major portion of elephant diet in the Mudumalai Wildlife Sanctuary. The most important species were Themeda spp and Apluda mutica. The species variation of the grasses eaten can be attributed to the different geographical locations and forage preferred by wild elephants (McKay, 1973; Moss, 1988; Sivaganesan and Kumar, 1995; Mercy, 2002; Borah and Deka, 2008). The feeding habits of elephants show a great variation of species preference with respect to seasons, availability of water and movement pattern. Elephants in Sarguja region are well adapted to feed on various seasonal flora present round the year. There has been intensively logging during the past few years as the result of which many of the original tropical deciduous forest cover has disappeared.

From the point of elephant conservation, Sarguja region is a rich habitat but is under biotic pressure. Gajraj rehabilitation programme is still ongoing in this corridor. Therefore, in few of the areas elephant are utilizing all the forest compartments frequently to fulfill their routine requirements. Other major factors are agricultural expansion peripheral to the different forest ranges and increasing number of anthropogenic and developmental activities. Study indicated that 31 plant species were consumed by elephants as their food but it has been suggested that different populations of elephants in the same forest stretch use some separate and specific fodder species (as having different geological conditions) hence more information is needed on their feeding biology to properly develop management strategies for their conservation. Therefore, management practices are needed to conserve the elephant's habitat for their long-term survival. The study helped in knowing the food preference of elephants in the area and thus would contribute to management plans of the forest department and formulate actions to safeguard the habitat in the long run.

\section{Conclusion}

The present study revealed that major food species for elephants comprised of grasses, shrubs, tree leaves, bark and fruits and their feeding is dependent on migration and movement pattern. Majority of the tree species were found near the villages which is also a major cause of HEC. Study further indicated that few of the fodder species are common throughout the year while few are only available in particular season. Pugmarks analysis indicated direct proportional correlation between pugmark impression with feeding and movement pattern along the corridors. It also observed that frequency of conflicts were going high with the period of crop maturity. Mitigation measures like facilitating food and shelter, incorporating unpalatable crops like chilly, citrus and tobacco, etc in cropping systems and alternative elephant deterrent cash crop, opening up elephant corridors for free movement, corridors zonation, live fencing, permanent drinking water facility, etc. Eco-development initiatives need to be addressed in the forest fringe villages, along with a series of conservation education and awareness programmes with participatory approach. As a long term measure, restoration plan is of utmost necessity. Protection and proper management planning should be immediately made to foster natural regeneration of forest which in turn create favourable environment to elephants.

\section{ACKNOWLEDGEMENTS}

The authors are thankful to Sarguja Forest Department, Ambikapur, Chhattisgarh for supports and people of the study areas for sharing the knowledge and valuable information.

\section{REFERENCES}

Areendran, G., Raj, K., Mazumdar, S., Munsi, M., Govil, H. and Sen, P. K. (2011). Geospatial modeling to assess elephant habitat suitability and corridors in northern Chhattisgarh, India. Tropical Ecology, 52(3): 275-283

Borah, J. and Deka, K. (2008). Nutritional evaluation of forage preferred by wild elephants in the Rani Range Forest, Assam, India. Gajaha, 28: 41-43

Borah, R.K. and Bhuyan, N. (2016). A comprehensive study of human-elephant conflict in the bordering areas of the three reserve forests of Lakhimpur district, Assam. International Journal of Interdisciplinary Research in Science Society and Culture, 2(1): 132-143

Chambers, R. (1994). The origins and practice of participatory rural appraisal. World Development, 22(7): 953-969

Dharmaratne, M.P.J. and Magedaragamage, P.C. (2014). Human-Elephant conflict and solution to it in Sri Lanka. Sciscitator, 1: 56-58

EMS (2008). A Home for Elephants, People and Tribal Communities: Managing Human Elephant Conflict in Chhattisgarh. Detailed Project Report. Earth Matters Foundation, New Delhi.

Graham, M.D., Notter, B., Adams, W.M., Lee, P.C. and Ochieng, T.N. (2010). Patterns of crop-raiding by ele- 
phants, Loxodonta africana, in Laikipia, Kenya, and the management of human- elephant conflict. Syst. Biodiver., 8: 435-445

Gubbi, S. (2012). Patterns and correlates of human-elephant conflict around a south Indian reserve. Biological Conservation, Doi:10.1016/j.biocon.2012.01.046.

Hedges, S. and Gunaryadi, D. (2009). Reducing humanelephant conflict: do chillies help deter elephants from entering crop fields? Oryx - Int. J. Conserv., 44: 139146

Ishwaran, N. (1983). Elephant and woody-plant relationships in Gal Oya Sri Lanka. Biological Conservation, 26: 255 $-270$

Jhariya, M.K. and Yadav, D.K. (2016). Understorey vegetation in natural and plantation forest ecosystem of Sarguja (C.G.), India. Journal of Applied and Natural Science, 8(2): 668-673

McKay, G.M. (1973). Behaviour and Ecology of the Asiatic Elephants in SoutheasternCeylon. Smithsonian Contributions to Zoology 125, Smithsonian Institution Scholarly Press, Washington D.C.

Mercy, A.D. (2002). Feeding of elephant. Journal of Indian Veterinary Assoc., 7(3): 18-20

MoEF. (2010). Gajah: Securing the future for elephants in India. GoI, New Delhi, India.

Moss, C. (1988). Elephant memories, Thirteen years in the Life of an Elephant Family. William Morrrow and Co. Inc, New York.

Mueller-Dombois, D. (1972). Crown distortion and elephant distribution in the woody vegetation of Ruhunu National Park, Ceylon. Ecology, 53: 208- 226

Prabu, M. and Kumar, G.P. (2016). Review on recent advances in elephant tracking and detection: a sensorial approach. Asian Journal of Information Technology, 15 (6): 1132-1138

Santiapillai, C. and Read, B. (2010). Would masking the smell of ripening paddy-fields help mitigate humanelephant conflict in Sri Lanka? Oryx, 44: 509-511

Senthikumar, K., Mathialagan, P., Manivannan, C., Jayathangaraj, M.G. and Gomathinayagam, S. (2016). A study on the tolerance level of farmers toward humanwildlife conflict in the forest buffer zones of Tamil Nadu. Veterinary World, 9(7): 747-752
Singh, R.K. (2002). Elephants in exile: A rapid assessment of the Human-Elephant conflict in Chhattisgarh. An Occasional Report of a Rapid Action Project as part of the Elephant Conservation Project. Occasional Report No. 5, Wildlife Trust of India, New Delhi.

Sinha, R., Jhariya, M.K. and Yadav, D.K. (2015). Assessment of Sal Seedlings and Herbaceous Flora in the Khairbar Plantation of Sarguja Forest Division, Chhattisgarh. Current World Environment, 10(1): 330337

Sinha, R., Yadav, D.K. and Jhariya, M.K. (2014). Growth performance of Sal in Mahamaya central forest nursery (Ambikapur), Chhattisgarh. International Journal of Scientific Research, 3(11): 246-248

Sivaganesan, N. and Johnsingh, A.J.T. (1995). Food resources crucial to the wild elephants in Mudumalai Wildlife Sanctuary, South India. In: A Week with Elephants (J.C. Daniel and H.S. Datye, eds.), pp. 405-423. Bombay Natural History Society/Oxford University Press, Bombay.

Sivaganesan, N. and Kumar, A. (1995). Status of feral elephants in Andaman. In: Week with Elephants. Daniel, J.C. And Datye, H.S. (eds.). Proceedings of the International Seminar on the Conservation of Asian Elephant, Bombay Natural History Society, New Delhi, Pp. 97117

Sukumar, R. (1991). The management of large mammals in relation to male strategies and conflict with people. Biol. Conserv., 55: 93-102

Sukumar, R. (1985). Ecology of the Asian Elephant (Elephas maximus) and It's Interaction with Man in South India. Unpublished Ph.D. Thesis, Indian Institute of Science, Bangalore.

Thakur, A.K., Yadav, D.K. and Jhariya, M.K. (2015). Human-elephant conflict scenario in corridors of Northern Chhattisgarh. Journal of Plant Development Sciences, 7 (11): 821-825

Vancuylenberg, B.W.B. (1977). Feeding behavior of the Asiatic elephant in southeast Sri Lanka in relation to conservation. Biological Conservation, 12: 33-54

Yadav, D.K., Jhariya, M.K., Kumar, A. and Sinha, R. (2015). Documentation and ethnobotanical importance of medicinal plants found in Sarguja district. Journal of Plant Development Sciences, 7(5): 439-446 